\title{
sciendo
}

\section{Knowledge-based HR Practices and Innovation in SMEs}

\author{
Mohammad Jaber Yousef AL-TAL, Okechukwu Lawrence EMEAGWALI
}

\author{
Girne American University, Faculty of Economics and Business, Business Management Department, \\ via Mersin 10, North Cyprus, Turkey \\ mohamad.al-tal@lob.gov.jo, lemeagwali@outlook.com
}

\begin{abstract}
Background and purpose: Recent reviews of the human resource management (HRM) literature continue to position knowledge management and intellectual capital as the key determinants for competitiveness, productiveness and organizational performance. This article explores the nexus between knowledge-based HRM practices, knowledge management capacity, intellectual capital, product and process innovation in small and medium-sized enterprises (SMEs).

Design/Methodology/Approach: Data were gleaned from 250 registered SMEs in Jordan using a simple random sampling technique. A covariance structural equation modelling (CB-SEM) was deployed in testing the proposed research model.

Results: The findings cast light on the positive influence of knowledge-based HRM practice of SMEs on SMEs knowledge management capacity, intellectual capital and, product and process innovation. Similarly, knowledge management capacity SMEs exerts positive impact on their intellectual capital and, product and process innovation. Intellectual capital also emerges as a strong predictor for SMEs product and process innovation. Finally, a serial indirect effect (mediation) of knowledge management capacity and intellectual capital on the relationship between knowledge-based HRM practice of SMEs and, product and process innovation were revealed.

Conclusion: Knowledge-based HRM practices and innovation have received vast amount of research attention, yet there is a lack of understanding on the process by which the former leads to the latter. Drawing on knowledge-based view (KBV) theory, this study is among the first attempts to unveil the structural process between knowledge-based HRM practices and innovation through knowledge management capacity and intellectual capital. This study theoretically validated the KBV framework in a non-Western context and demonstrate the importance of knowledge-based HRM practices for SMEs innovativeness. The findings do not only provide useful insights for managers and scholars, but also serve as the building block for future research.
\end{abstract}

Keywords: HR Practices; intellectual capital; product innovation; process innovation; knowledge capacity

\section{Introduction}

Human resource management contributes greatly to attracting talented individuals to organization even at the face of increasing competition from both the global economy and knowledge economy. Hence, understanding HRM may proof to be more than significant in enticing, selecting, positioning, retaining and transforming valuable human resource in creating innovative process and products. Knowledge-based human resource practice involves functions and activities that ensures identification and recruitment of talented individuals with specific potentials that can be harnessed to enhance organizational competitiveness through knowledge management capacity improvement. According to Martinez-Conesa, Soto-Acosta and Carayannis (2017), firms including small and medium-sized enterprises (SMEs) are nowadays depending more on external information and joint efforts to gain competitive advantage through innovation that can enable them to compete globally (Martinez-Conesa et al., 2017; Soto-Acosta, Popa, \& Palacios-Marqués, 2017). Collaborative networks with external firms has been identified as a

Received: September 11, 2018; revised: January 8, 2019; accepted: January 22, 2019 
main conduit to channel information and benefit from their new expertise, skills and technologies (Huggins \& Thompson, 2015; Petruzzelli, 2011).

Specifically, when SMEs context is taken into consideration, sustainable competitiveness requires purposive inflows and outflows of knowledge due to the fact that SMEs face more severe resource constraints (Spithoven, Vanhaverbeke, \& Roijakkers, 2013). In the same vein, innovation is also a function of knowledge capabilities of the organization. Beyond the influence of human resource management and knowledge management, intellectual capacity defined as 'intellectual material - knowledge, information, experience, core technique, intellectual property, and customer relationship - that can be put to use to create wealth (Stewart, 1997) has also been shown in previous studies to influence firms' innovativeness (Donate, Peña, \& de Pablo, 2016; Manzaneque, Ramirez, \& Diéguez-Soto, 2017; Yang, \& Lin, 2009).

Organizations nowadays are beginning to realize the emergence of knowledge resource dominated society in which the competitive landscape is twitted by its intellectual capital allocation (Bontis, 2004). Scholars highlighted the move of power from tangibles to intangibles such as intellectual capital in creating organizations' wealth and progress (Yang \& Lin, 2009); thus, making intellectual capital a pivotal component of organizations' lasting success. Several studies suggested that for innovation process to be functional, knowledge must be a definite input (e.g., Easterby-Smith, Lyles, \& Tsang, 2008; Miller, Fern, \& Cardinal, 2007; Perry-Smith \& Mannucci, 2017; Rodan \& Galunic, 2004; Singh, Kryscynski, Li, \& Gopal, 2016). Hence, knowledge-based conditions such as knowledge-based HRM, knowledge management capacity of the firms and intellectual capital may be considered critical in responding to the business environment dynamics effectively.

This study is motivated by the scantiness of research on the role of HRM, intellectual capital and KMS in predicting innovation. With the exception of scholars like Jiang, Wang and Zhao (2012); Wang and Chen (2013) who investigated the interactions between intellectual capital and HRM on innovation; De Saá-Pérez and Diaz-Diaz (2010) who studied the influences of HRM on innovation argued that there has been dearth of empirical research in this domain. Prior findings suggested that innovation in firms is largely enabled by knowledge-based HRM practices (Inkinen, Kianto, \& Vanhala, 2015; Kianto et al., 2017). What is lacking is an empirical evidence on the knowledge chain process; thus, the current research has some significant empirical contribution to the body of knowledge and practice by linking knowledge-based HRM practices, knowledge management capacity, intellectual capital and innovation in SMEs.

Scholars have sought to develop knowledge-based view or knowledge-based theory (KBV) of the firms mostly in Western firms. KBV abstractions are seeks to explain how knowledge as a resource influences efficient production and offers competitive advantage. Prior studies have focused on the input and output dimensions omitting the underlying factors that helps in translating such practices into success (Abubakar et al., 2017; Jordão \& Novas, 2017; Kianto et al., 2014; 2017). To expound the underlying dynamics, this paper contends and theoretically link knowledge-based HRM practices to knowledge accumulation, which is further transfer to employees, the accumulation of employee's intellectual capital can interpret a firm's ability in terms of innovation. With regards to context theoretical contribution, this paper expands the knowledge in literature on the interaction of HRM, knowledge management, intellectual capital and innovation in a non-Western context, technically interrogating theories and concepts developed in the Western World.

\section{Literature review}

Even though HRM dynamics are difficult to predict in the future, there are compelling indications that its practice and theory will be consistently metamorphose due to new technologies, globalization and fundamental changes in the workplace and nature of jobs. For instance, in Western countries, HRM practices have become an effective and efficient tool for achieving sustainable competitive advantage (Combs, Liu, Hall, \& Ketchen, 2006). High performance HRM practices can create value for and to organizations (Sun \& Pan, 2011). While, strategic HRM practices emphasize on developing no-tradeable, imperfectly imitable and durable people resources (Bamberger et al., 2014). Nonetheless, both approaches see HRM as a system by which people are directed and managed to achieve sustainable competitive advantage (Kehoe \& Wright, 2013). According to Damodaran and Olphert (2000), knowledge management systems (KMS) are "information systems that are perceived to facilitate organizational learning by capturing both content and process knowledge and making these knowledge available to all employees" (pg.11). Abubakar et al. (2017) added that "knowledge management involves several elements like human resources practices, technology, culture and organizational structures; which makes it a meticulous approach toward the optimization of a firm's knowledge economy as well as innovations" (pg.13). Implementation of KMS is not just a technological concern but also involve human factor (Shrafat, 2017). Which could be translated into knowledge-based HRM practices. 


\subsection{Knowledge-based human resource management (HRM) practices}

Training and development, recruitment and selection, compensation and performance evaluation are the main determinants of organizational effectiveness (Delaney \& Huselid, 1996). Knowledge-based HRM practices include HRM practices deliberately designed to improve organization's knowledge process. Managers need to modify the traditional HRM practices to improve knowledge creation and sharing in their organizations (Jahmani et al., 2018).

\subsubsection{Knowledge-based recruitment}

Recruitment "includes those activities carried out with the primary purpose of identifying and attracting potential employees i.e. human capital" (Breaugh \& Starke, 2000, p. 45). It is important that recruiting officers should select employees not only based on their current skills, knowledge or experience but also based on the employees' potential. Jiang et al. (2012) opined that employees that have potentials are more inclined to learning, acquiring the knowledge or skills required for innovation. In a nutshell, knowledge-based recruitment embroils an explicit and strong emphasis on selecting candidates with pertinent networking, learning and knowledge capabilities.

\subsubsection{Knowledge-based performance assessment}

Performance assessment is a very important and relevant means of directing employee behavior. It is expedient that managers explicitly and consciously include performance criteria to knowledge process (knowledge creation, application and sharing) to enhance these processes. Performance evaluation emphasize feedback and development (Weisman, 1999), feedbacks help in identifying disparities between performance and targets (Shipton et al., 2006), as this will motivate employees to work innovatively (Jiang et al., 2012). Additionally, assessments that emphasize learning and growth will help employees in gaining the confidence required to harness the opportunities for better learning (Jiang et al., 2012). Concisely, knowledge-based performance assessments evaluate employees based on their contribution and involvement in improving the organization's knowledge process e.g., knowledge creation, sharing and application (Alavi \& Leidner, 2001).

\subsubsection{Knowledge-based training}

Robbins, Judge and Campbell (2010) revealed that it is not possible for competent employees to remain competent forever as skills often depreciate and become passé. De- signing and implementing training and development activities for employees will help in optimizing the fit between employees' requisite and present skills and knowledge which will improve the organization's human capital (Cabello-Medina et al., 2011) and contribute to the employees' knowledge creation abilities (De Winne \& Sels, 2010). According to Lau and Ngo (2004), training will also enhance employees' work domain expertise as well as their creative thought process. To be concise, knowledge-based training and development entails regular development of employees' expertise and knowledge comprehensively, by personalizing training to fit employees' peculiar needs and ensuring a continuous development.

\subsubsection{Knowledge-based compensation}

According to Kianto et al. (2017), organizational compensation policies help in promoting knowledge management within the organization. Managers often use both intangible (such as recognition and status) and tangible incentives (such as one-off rewards and bonuses) to encourage knowledge sharing, creation and application among employees. Past research revealed that for employees to share, apply knowledge and create new ideas, incentive systems must be put in place like (Hussinki, Ritala, Vanhala, \& Kianto, 2017; Inkinen et al., 2015; Kianto, Ritala, Spender, \& Vanhala, 2014) . This means that knowledge-based compensation is recompensing employees based on their contributions to the organization's key knowledge process involving knowledge creation, sharing and application.

\subsubsection{Knowledge-based career management}

Career management is a means of retaining and attracting high performing employees. Lewis and Arnold (2012) believed that high performing employees have higher opportunities within the organization. The major components of effective knowledge-based career management involve the use of support from top management, skill assessment activities, knowledge creation, sharing and application for career progression of the employees. In essence, knowledge-based career advancement is using new knowledge acquired from the organization's knowledge development program to help employees achieve their career goals and to improve the employees' productivity (Mahdavi, Mazdeh, \& Hesamamiri, 2014). 


\section{Theoretical framework and hypotheses}

\subsection{Knowledge-based HRM practices and knowledge management capacity}

In accordance with the tenets of knowledge-based theory (KBV), firms exist to create, integrate and utilize knowledge (Kogut \& Zander, 2003; Nonaka \& Takeuchi, 1995). Thus, knowledge is a crucial resource that ensures firms success and survival in complex and ambiguous environment that imitation rarely works (Subramaniam \& Youndt, 2005; Zack, McKeen, \& Singh, 2009). HR practices itself can be considered as a way of managing knowledge (Cabrera \& Cabrera, 2005; Lin, 2011), thus, modern HR practices are required to encourage employees for knowledge generation and application. Yang and Lin (2009) suggested that organizations increase their knowledge capacity by employing the right kind of people. The strength of an organization's human capital is seen in the nature of investment organization is willing to commit to its hiring process. Knowledge-based HRM practices that seek individuals with right potential for knowledge development through effective knowledge-based hiring, recruiting and selection, training, and compensation will foster knowledge management capacity of a firm. Following this line of argument, the following hypothesis is formulated:

H1: Knowledge-based HRM practices has a positive impact on knowledge management capacity of SMEs

\subsection{Knowledge-based HRM practices and intellectual capital}

Knowledge-based HRM is concerned with creating and implementing knowledge driven policies, systems and procedures to motivate employees' attitude and behaviors towards performance and innovation. Intellectual capital encompasses structural elements (i.e., expertise, knowhow, customer relationships, social values, norms, and professional skills) of firms that encourages employee's ability to generate wealth and value (Yang \& Lin, 2009). With the structural relation dimension of intellectual capital, firms can also enhance their process innovativeness, efficiency, transactional time and access to knowledge codified for the organization (Serenko, Bontis, \& Hull, 2016). Knowledge-based HRM practices is regarded as an investment in organization's human capital (Snell \& Dean, 1992), as it has been shown to inspire employees learning which facilitates intellectual capital development. Scholars like (Collins \& Clark, 2003; Martinsons, 1995) argued that firms shape the skills of their employees through the development of HRM. Therefore, SMEs can also generate greater intellectual capital in their establishments by implementing knowledge-based HRM. Following this line of argument, the following hypothesis is formulated:

H2: Knowledge-based HRM practices has positive impact on the intellectual capital of SMEs employees

\subsection{Knowledge-based HRM practices and product and process innovations}

HRM practices play an important role on incremental and radical innovations. Prior scholarly works have confirmed the influence of HRM practices on innovation (e.g., GilMarques \& Moreno-Luzon, 2013; Moreno-Luzon et al., 2013). Recent examinations further established the association of HR practices and organizational innovativeness (e.g., Hussinki et al., 2017; Inkinen et al., 2015; Kianto et al., 2014, 2017). KMS with a focus on HRM practices make use of existing knowledge in the organization to solve problems faster and easier (Zack et al., 2009). Thus, it can be concluded that knowledge management is critical in improving organization's innovation capacity. For instance, Darroch and McNaughton (2002) alluded that knowledge-oriented practices usually share relationship with innovation performance. In his research, Zack et al. (2009) established a significant positive relationship between research and development, knowledge acquisition by employees and firms' innovation. Thus, firm' innovativeness is based on promoting KMS practices that will generate new ideas and knowledge (Ozlen \& Handzic, 2014). Following this line of argument, the following hypothesis is formulated:

H3: Knowledge-based HRM practices has positive influence on product and process innovations of SMEs

\subsection{Knowledge management capacity and intellectual capital}

Intellectual capital has been investigated alongside knowledge management (Hussinki et al., 2017; Inkinen et al., 2015; Kianto et al., 2014). In the core of intellectual capital, experience, intellectual property, information and knowledge are combined to create value (Jordão \& Novas, 2017). Scholars argued that the uniqueness of knowledge applied by an organization in its generation of competitive advantage signifies the strength of the organizations' competitiveness (e.g., Engelman et al., 2017; Gonzalez, Arrondo, \& Carcaba, 2017; Mendoza, 2017). As such, the quality of knowledge available to an organization through its knowledge acquisition, use and storage mechanism may impact the nature of intellectual capital developed in the organization. Intellectual capital cannot be described without the inclusion of relational capital and structural capital all of which requires adequate knowledge manage- 
ment capacity to harness. Following this line of argument, the following hypothesis is formulated:

H4: Knowledge management capacity has positive influence on intellectual capital of SMEs employees

\subsection{Knowledge management capacity and product and process innovations}

Within the framework of KBV, knowledge is viewed as the most important resources with which organizations can gain and sustain superior competitive advantage (Martinez-Conesa et al., 2017; Soto-Acosta, Popa, \& Palacios-Marqués, 2016). Complimenting this view, Lichtenthaler (2015) opined that an integrative KMS is required to successfully implement organizational innovativeness. Liao, Chuang and To (2011) added that KM capabilities of a firm must be well developed in order to assess and retort to competitors. On the other hand, product and process innovation requires gathering, sharing and utilization of existing and new knowledge in the firm (Rousseau, Mathias, Madden, \& Crook, 2016). SMEs that shows higher level of knowledge management capacity are likely to encounter a learning effect that can advance their competencies in rapid response to business dynamics, reduced redundancy and development of inventive ideas (Chang et al., 2013; Kianto et al., 2014). Beyond its importance in creating innovative products, a deep application of knowledge also ensures continuous translation of firms' expertise into personified products, and enhanced efficiency. Following this line of argument, the following hypothesis is formulated:

H5: Knowledge management capacity has positive influence on product and process innovations of SMEs

\subsection{Intellectual capital and product and process innovations}

Intellectual capital is seen as the entirety of knowledge resources both tangible and intangible that is available to a firm. Intellectual capital ensures that codified knowledge in databases, information systems and written procedures are available to contribute to product and process innovation (Wang \& Chen, 2013). Product and/or service innovation is the innovative effort of organizations that result in the creation of significantly improved or new goods or services in respect to its intended use. Whereas, innovation entails the generation of new knowledge as inputs in form of concepts and ideas or as output in form of novel products and processes. Accordingly, intellectual capital is more relevant in predicting innovation, which interprets innovation as an intrinsic activity, as such, its development will depend on human capabilities. Extant literature revealed that a possible association between intellectual capital and innovation exist (Hussinki et al., 2017; Obeidat et al., 2017). Following this line of argument, the following hypothesis is formulated:

H6: The intellectual capital of SMEs employees has positive influence on product and process innovations.

\subsection{Knowledge management capacity and intellectual capital as mediators}

Valuable novel knowledge is often generated and transformed into processes, services and products by changing the general knowledge into specific ones that benefits the organization (Siong, Kuan Yew, \& Lin, 2006). For instance, Massey, Montoya-Weiss and O'Driscoll (2008) argued that proper implementation of KMS can innovative process. The innovative efforts of firms involves probing for, and the unearthing, trying and development of new products or services, new technologies, new organizational structures, new processes and new productions (Likoum et al., 2018; López-Nicolás \& Meroño-Cerdán, 2011). Organizations invest in HRM activities in order to create sustained advantage which is often evident in their innovation capabilities. Rosenbach, Taylor and Youndt (2012) concluded that the relationship between HRM practices and organizational outcomes can be better understood through mediating role of intellectual capital. Knowledge-based HRM practices will facilitate knowledge management capacity, and the amount of this will determine the level of intellectual capital in the firm (Donate et al., 2016). Furthermore, high intellectual capital enables organization to develop innovative processes and products that are not easily imitable for competitors (Cabello-Medina et al., 2011). Thus, knowledge management capacity and intellectual capital can serve as functional elements in the relationship between knowledge-based HRM and innovation processes of SMEs. Following this line of argument, the following hypothesis is formulated:

H7: Knowledge management capacity and the intellectual capital of employees mediates the relationship between knowledge-based human resource management practices and product and process innovations of SMEs

The research model and proposed hypotheses are presented in Figure 1. 


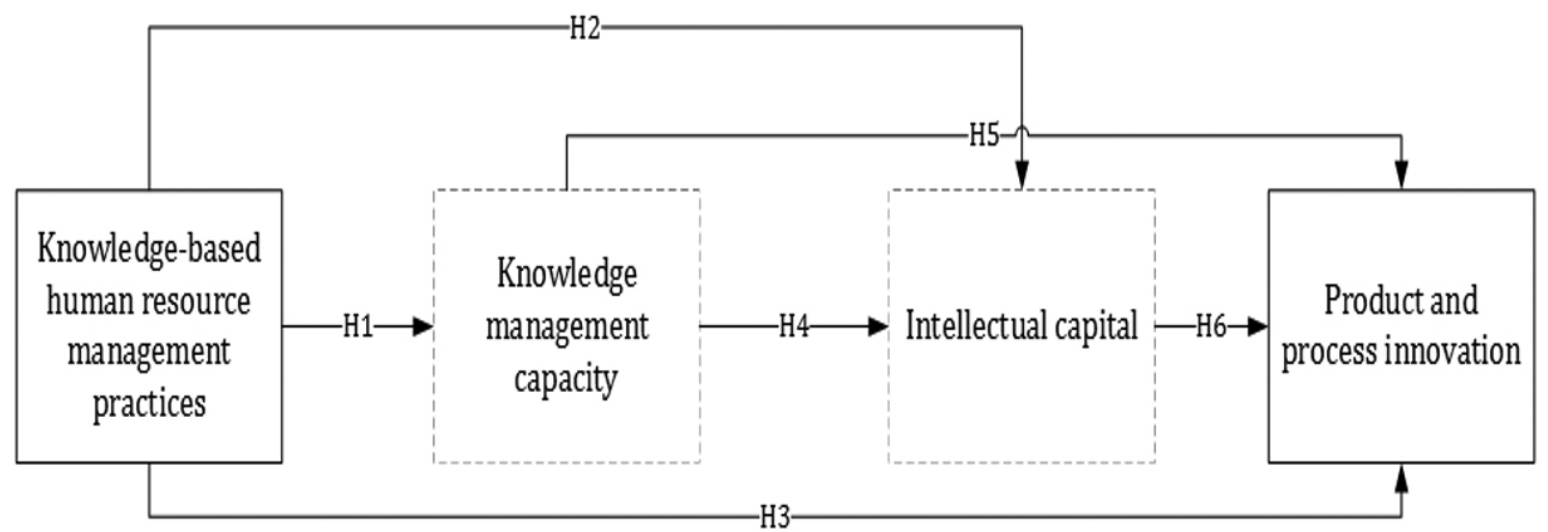

H7 - knowledge management capacity and intellectual capital as SERIAL MEDIATORs between knowledge-based human resource management practices, and product and process innovation link

Figure 1: Research model

\section{Method}

\subsection{Industrial context and sampling procedure}

Globalization and trade liberalization have ushered in new opportunities and challenges for SMEs in developing and less affluent countries like Jordan. This paper strives to evaluate how knowledge-based HRM practices in SMEs contributes to human capital development, knowledge accumulation, and competitiveness in terms of SMEs innovation in Jordan. Sharp (2015) estimated that 98\% of all enterprises in Jordan fall into SMEs category, the author concluded that the Jordanian economy is heavily reliant on SMEs activities and that the sector employs most of the incumbent workforce. The Ministry of Industry and Trade classify SME's based on the number of employees and the paid capital investment as summarized in the following table. Table 1. Based on the information obtained from the ministry, 1,400 registered SMEs are operating in Amman, Jordan (http://www.jordanyp.com/category/Small business/city:Amman).

The developed questionnaire was back-translated to Arabic and to English by professional translators following the procedures used by (Abubakar, Megeirhi, \& Shneikat, 2018; Perrewe et al., 2002). A test study was carried out with 15 people to determine the stability of the instruments. Like prior studies respondents were briefed about the intent of the research. Their "anonymity and confidentiality were assured to diminish social desirability bias and the threat of common method bias" as noted by (MacKenzie et al., 2011; Podsakoff et al., 2012). To propel the veracity and predictability of the research, simple random sampling technique was utilized to select participating HR managers and executives of the Jordanian SMEs. At the end 250 valid responses were obtained, and consequently used for data analysis.

\subsection{Measures}

Knowledge-based HRM practices were captured with 13 items utilized by Kianto, Sáenz and Aramburu (2017) study. Knowledge management capacity was captured with 8 items utilized by Chen and Huang (2009) study. Intellectual capital was captured with 3 items utilized by Yang and Lin (2009) study. Product and process innovation captured with 13 items utilized by Škerlavaj, Song and Lee (2010) and Elrehail et al. (2018). The items were formulated on a 5-point response scale, and scores closer to 5 indicate a higher score.

Table 1: SMEs taxonomy in Jordan

\begin{tabular}{|l|l|l|}
\hline Firm Category & $\begin{array}{l}\text { Investment Size } \\
\text { (Dinar) }\end{array}$ & $\begin{array}{l}\text { No. of } \\
\text { Employees }\end{array}$ \\
\hline Micro & Less than 30,000 & $1-9$ \\
\hline Small & 30,000 & $10-49$ \\
\hline Medium & 30,000 & $50-249$ \\
\hline Large & 30,000 & 250 and above \\
\hline
\end{tabular}


Table 2: Demographic information of the participating SMES

\begin{tabular}{|l|c|c|}
\hline & Frequency & $\%$ \\
\hline \multicolumn{2}{|c|}{$\boldsymbol{R} \boldsymbol{D}$ intensity- qualifications of the personnel hired in } & $\boldsymbol{R} \& \boldsymbol{D}$ department \\
\hline Some college degree & 34 & 13.6 \\
\hline Bachelor's degree & 145 & 58.0 \\
\hline Higher degree & 71 & 28.4 \\
\hline Total & 250 & 100.0 \\
\hline Incumbent employees & 92 & 36.8 \\
\hline Less than 50 & 140 & 56.0 \\
\hline 51 - 100 & 18 & 7.2 \\
\hline Above 100 & 255 & 100.0 \\
\hline Total & \multicolumn{2}{|c|}{} \\
\hline Operating sector & 50 & 20.0 \\
\hline Manufacturing firm & 200 & 80.0 \\
\hline Service firm & 250 & 100.0 \\
\hline Total & \multicolumn{2}{|c|}{} \\
\hline
\end{tabular}

\subsection{Analytical strategy}

In regard to analytic strategy, the author first obtained 250 valid responses. As a first step, participating SMEs demographic set-ups were gauge using frequency analysis in SPSS. Then, the author assesses the representativeness of the participating SMEs by comparing their demographics make-up with that of the general SMEs in Jordan. In doing, the author addresses the potential threat of response bias. As a second step, the researcher assesses the validity and reliability and the theoretical structural of the factors under investigation. To achieve this, confirmatory factor analysis (CFA) was employed in AMOS program, indicators examined include standardized factor loadings (SFL), discriminant and convergent validity, as well as reliability of the variables under investigation.

\section{Data analysis and results}

\subsection{Sample breakdown}

In table 2, the author illustrates the demographic breakdown of the participating SMEs. The profile of the SMEs is respect to employee numbers indeed reflects The Jordanian Ministry of Industry and Trade SMEs classification.

\subsection{Measurement model}

Measurement model assessments and hypotheses testing were conducted using structural equation modelling (SEM) with IBM SPSS AMOS. Confirmatory factor anal- ysis (CFA) is "a statistical technique used to verify the factor structure of a set of observed variables (Harrington, 2008); which aid researchers to identify and determine construct validity that encompass convergent and discriminant validity" (Bagozzi, 1980; Bagozzi, \& Heatherton, 1994; Bagozzi, \& Yi, 1988). Convergent validity and discriminant were gauge using standardized factor loadings (SFL), composite reliability (CR), average variance extracted (AVE) and Cronbach's alpha $(\alpha)$ for scale reliability. The modeling yielded the following outcome for a four-factor model: $\left(\Delta \chi^{2}=, \chi^{2}=1016.103, \chi^{2} / \mathrm{df}=1.631\right.$, $\mathrm{GFI}=.820, \mathrm{NFI}=.916, \mathrm{IFI}=.966, \mathrm{TLI}=.963, \mathrm{CFI}=.966$, $\mathrm{RMR}=.024, \mathrm{RMSEA}=.050$, PCLOSE $=.000)$. The model fit indices exhibited by the single factor modeling yielded a poorer fit highlighting that the measurement model is not affected by CMB and/or CMV (Podsakoff et al., 2003; Podsakoff et al., 2012). The scale items also exhibited high standardized factor loadings that spaning from .835 to .878); with significant t-values that spans from 17.647 to 19.289. These criteria meet those set-forth by (Anderson \& Gerbing, 1988; Fornell, \& Larcker, 1981). See Table 3.

The study's alpha value exceeded .70 (Nunnally, 1976), the CR value exceeded the index, .60 (Hair et al., 2010), and AVE values are more than .50 (Anderson \& Gerbing, 1988). It is on this premise that we concluded that the model of interest has achieve both convergent and divergent validity with good internal consistency. Inter-correlations, mean and standard deviations of the variables in the research model are reported in Table 4. We uncover that knowledge-based HRM has a positive and significant relationship with knowledge management capacity $(r=$ $.959, p<.001)$; intellectual capital $(r=.937, p<.001)$ and product and process innovation $(r=.975, p<.001)$. 
Table 3: Descriptive statistics of the survey items

\begin{tabular}{|c|c|}
\hline Variables & SFL(t-value) \\
\hline \multicolumn{2}{|l|}{ KNOWLEDGE-BASED HRM } \\
\hline \multicolumn{2}{|l|}{ Knowledge-based HRM - Recruiting and selection } \\
\hline "When recruiting, we pay special attention to relevant expertise" & $859(-)$ \\
\hline "When recruiting, we pay special attention to learning and development ability" & $.856(18.495)$ \\
\hline "When recruiting, we evaluate the candidates" ability to collaborate and work in various networks" & $.878(19.401)$ \\
\hline \multicolumn{2}{|l|}{ Knowledge-based HRM - Training and development } \\
\hline "We offer our employees opportunities to deepen and expand their expertise" & $.854(18.399)$ \\
\hline "We offer training that provides employees with up-to-date knowledge" & $.872(19.175)$ \\
\hline $\begin{array}{l}\text { "Our employees have an opportunity to develop their competence through training tailored to specific } \\
\text { needs" }\end{array}$ & $.871(19.095)$ \\
\hline "Competence development needs of employees are discussed with them regularly" & $.846(18.082)$ \\
\hline \multicolumn{2}{|l|}{ Knowledge-based HRM - Performance assessment } \\
\hline "The sharing of knowledge is one of our criteria for work performance assessment" & $.857(18.533)$ \\
\hline "The creation of new knowledge is one of our criteria for work performance assessment" & $.835(17.647)$ \\
\hline $\begin{array}{l}\text { "The ability to apply knowledge acquired from others is one of our criteria for work performance Assess- } \\
\text { ment" }\end{array}$ & $.870(19.077)$ \\
\hline \multicolumn{2}{|l|}{ Knowledge-based HRM - Compensation } \\
\hline "Our company rewards employees for sharing knowledge" & $.838(17.781)$ \\
\hline "Our company rewards employees for creating new knowledge" & $.851(18.293)$ \\
\hline "Our company rewards employees for applying knowledge" & $.859(18.589)$ \\
\hline \multicolumn{2}{|l|}{ Intellectual Capital } \\
\hline "Our employees are highly skilled at their jobs" & $.855(18.035)$ \\
\hline "Our employees are highly motivated in their work" & $.861(18.256)$ \\
\hline \multirow[t]{2}{*}{ "Our employees have a high level of expertise" } & $.859(18.589)$ \\
\hline & $.845(-)$ \\
\hline \multicolumn{2}{|l|}{ KNOWLEDGE MANAGEMENT CAPACITY } \\
\hline \multicolumn{2}{|l|}{ Knowledge management capacity - acquisition } \\
\hline "Knowledge was obtained from customers" & $.853(-)$ \\
\hline "Knowledge was obtained from partners" & $.869(18.720)$ \\
\hline "Knowledge was obtained from employees" & $.868(18.703)$ \\
\hline \multicolumn{2}{|l|}{ Knowledge management capacity - sharing } \\
\hline "Knowledge was shared between supervisors and subordinates" & $.854(18.150)$ \\
\hline "Knowledge was shared between colleagues" & $.871(18.827)$ \\
\hline "Knowledge was shared between units" & $.860(18.379)$ \\
\hline \multicolumn{2}{|l|}{ Knowledge management capacity - application } \\
\hline "Effectively managing knowledge into practical use" & $.864(18.536)$ \\
\hline "Effectively utilizing knowledge into practical use" & $.858(18.288)$ \\
\hline \multicolumn{2}{|l|}{ PRODUCT AND PROCESS INNOVATION } \\
\hline \multicolumn{2}{|l|}{ Product and service (technical) innovations } \\
\hline "In new product and service introduction, our company is often first-to-market" & $.850(18.518)$ \\
\hline "Our new products and services are often perceived as very novel by customers" & $.850(18.490)$ \\
\hline "New products and services in our company often take us up against new competitors" & $.848(18.451)$ \\
\hline
\end{tabular}


Table 3: Descriptive statistics of the survey items (continued)

\begin{tabular}{|l|l|}
\hline $\begin{array}{l}\text { "In comparison with competitors, our company has introduced more innovative products and services } \\
\text { during past } 5 \text { years" }\end{array}$ & $.868(19.289)$ \\
\hline "We constantly emphasize development of particular and patent products" & $.849(18.461)$ \\
\hline "We manage to cope with market demands and develop new products quickly" & $.851(18.529)$ \\
\hline "We continuously modify design of our products and rapidly enter new emerging markets" & $.866(19.195)$ \\
\hline "Our firm manages to deliver special products flexibly according to customers" orders" & $.857(18.785)$ \\
\hline "We continuously improve old products and raise quality of new products" & $.861(18.957)$ \\
\hline Process (administrative) innovations & $.865(17.951)$ \\
\hline "Development of new channels for products and services of our corporation is an on-going process" & $.851(19.108)$ \\
\hline "We deal with customers' suggestions or complaints urgently and with utmost care" & .864 (18.548) \\
\hline $\begin{array}{l}\text { "In marketing innovations (entering new markets, new pricing methods, new distribution methods, etc.) our } \\
\text { company is better than competitors" }\end{array}$ & $.836(-)$ \\
\hline $\begin{array}{l}\text { "We constantly emphasize and introduce managerial innovations (e.g. computer-based administrative inno- } \\
\text { vations, new employee reward/training schemes, new departments or project teams, etc.)" }\end{array}$ \\
\hline
\end{tabular}

Note: $\chi 2$-Chi-square; $\chi 2$ /df (CMIN/DF) - Relative Chi-square; The GFI (goodness of fit index); The normed fit index (NFI), Incremental fit index (IFI); The Tucker-Lewis coefficient (TLI); The comparative fit index (CFI); The RMR (root mean square residual). The Root Mean Square Error of Approximation (RMSEA); SFL, standardized factor loadings; -* discarded items during confirmatory factor analysis

Table 4: Correlation coefficient and measures descriptive statistics Note: ${ }^{* *} \rho$-value $<.001 ;{ }^{*} \rho$-value $<.05$;

\begin{tabular}{|c|c|c|c|c|}
\hline Variables & 1 & 2 & 3 & 4 \\
\hline 1. Knowledge-Based HRM & - & & & \\
\hline 2. Knowledge Management Capacity & $.959 * *$ & - & & \\
\hline 3. Intellectual Capital & $.937 * *$ & $.930 * *$ & - & \\
\hline 4. Product and Process Innovation & $.975 * *$ & $.962 * *$ & $.933 * *$ & - \\
\hline Mean Score & 3.709 & 3.712 & 3.679 & 3.733 \\
\hline Standard Deviations & .942 & .976 & .989 & .941 \\
\hline Composite reliability & .973 & .959 & .890 & .973 \\
\hline Cronbach's alpha & .973 & .959 & .890 & .972 \\
\hline Average variance extracted & .735 & .743 & .729 & .731 \\
\hline
\end{tabular}

Secondly, knowledge management capacity has a positive and significant relationship with intellectual capital $(r$ $=.930, p<.001)$ and product and process innovation $(r=$ $.962, p<.001)$. Finally, intellectual capital exerts a positive and significant relationship with product and process innovation $(r=.933, p<.001)$. These outcomes suggests that the variables under investigation are closely related and are in harmony with the theoretical framework.

\subsection{Structural model}

AMOS v.21 was used to test the structural model and hypotheses. See figure 2. Table 5 presents seven impor- tant findings that are worth listing, as expected knowledge-based HRM practice exerts a positive and significant impact on knowledge management capacity $(\beta=.959, p<$ $.001)$; intellectual capital $(\beta=.555, p<.001)$, and product and process innovation $(\beta=.600, p<.001)$. This lead us to support hypothesis 1, 2 and 3 . Furthermore, knowledge management capacity SMEs exerts a positive and significant impact on intellectual capital $(\beta=.399, p<.001)$ and product and process innovation $(\beta=.311, p<.001)$. This lead us to support hypothesis 4 and 5. Similarly, Intellectual capital of SMEs exerts a positive and significant impact on product and process innovation $(\beta=.082, p<$ $.05)$. Thus, hypothesis 6 was supported.

Hayes (2015) added that one of the beauties of boot- 
strapping is that the inference is based on an estimate of the indirect effect itself, but unlike the Sobel test, it makes no assumptions about the shape of the sampling distribution of the indirect effect, thereby getting around this problem that plagues the Sobel test. Based on the extant benefits and strengths of SEM and boostrapping. The researcher adopted bootstrapping analysis with bias-corrected confidence interval of $95 \%$ using a validation sample that is equals to 5,000 to test hypothesis 7 . The result shows that SMEs knowledge management capacity and their intellectual capital mediated the link between knowledge-based HRM practices and, product and process innovations $(\beta$ $=.375, \rho<.001)$. Bias-corrected estimates asserts that a partical mediation exist with $(\rho=.000,95 \%$ confidence interval: .262 - .480). This lead us to support hypothesis 7. See Table 6.

\section{Discussion and conclusion}

The literature is devoid of both empirical and theoretical evidence on the association between knowledge-based HRM knowledge management, intellectual capital and innovation in a non-Western work setting. The current study premise on this gap to by investigating the above said relationships, with the hope that the findings can be implemented by top management of organization who are concerned with transforming their human capital into organizational success, more specifically, innovations. This study is important as it unveils the mechanistic process that results in process and product innovation, as well as the combination of knowledge-based HRM practices, which has been proved to be an antecedent of intellectual capital. To spice up process, knowledge management notable antecedent of intellectual capital was considered. In doing so, this paper has enormous theoretical and empirical contributions to literature by interrogating and validating theories and concepts developed in the Western World in a non-Western context, Jordan

Firstly, this study confirmed knowledge-based HRM practices have positive influence on knowledge management capacity of SMEs. Suggesting that SMEs' propensity for knowledge management capacity development is a function of the nature of its human resource. This finding is in line with (Kang et al., 2012) findings. Firms with these practices can easily develop knowledge management capacity, thus, providing avenue for knowledge application that will in turn yield superior product offerings (Donate et al., 2016). Secondly, this paper revealed that knowledge-based HRM practices have positive influence on intellectual capital of SMEs employees. This finding also corroborates other in extant literature prior to the current study (Kianto et al., 2014; Ortiz et al., 2016).

Table 5: Structural equation modeling weights using maximum likelihood techniques

Note: $\beta$, standardized beta; beta standardized beta; SE, standard errors; *** $\rho$-value $<.001 ; * * \rho$-value $<.05$

\begin{tabular}{|c|c|c|c|c|c|}
\hline Variables & & $\boldsymbol{\beta}$ & Beta & SE & $\rho$ \\
\hline Knowledge-based HRM & - Knowledge management capacity & .959 & .993 & .019 & $* * *$ \\
\hline Knowledge-based HRM & - Intellectual capital & .555 & .582 & .077 & $* * *$ \\
\hline Knowledge-based HRM & - Product and Process Innovation & .600 & .599 & .049 & $* * *$ \\
\hline Knowledge management capacity & - Intellectual capital & .399 & .404 & .075 & $* * *$ \\
\hline Knowledge management capacity & - Product and Process Innovation & .311 & .300 & .045 & $* * *$ \\
\hline Intellectual capital & - Product and Process Innovation & .082 & .078 & .036 & $* *$ \\
\hline
\end{tabular}

Table 6: Effects bifurcation (total, direct and indirect) with 5,000 resample

Note: LO, lower bound; UP, upper bound; CI, confidence interval; *** $\rho$-value $<.001$; ** $\rho$-value $<.05$;

\begin{tabular}{|c|c|c|c|c|c|c|}
\hline Variables & & Total & Direct & Indirect & LO & UP \\
\hline Knowledge-based HRM & - Knowledge management capacity & .959 & .959 & .000 & & \\
\hline Knowledge-based HRM & - Intellectual capital & .937 & .555 & $.382 * * *$ & .213 & .550 \\
\hline Knowledge-based HRM & - Product and Process Innovation & .975 & .600 & $.375 * * *$ & .262 & .480 \\
\hline $\begin{array}{l}\text { Knowledge management } \\
\text { capacity }\end{array}$ & - Intellectual capital & .399 & .399 & .000 & & \\
\hline $\begin{array}{l}\text { Knowledge management } \\
\text { capacity }\end{array}$ & - Product and Process Innovation & .344 & .311 & $.033 * *$ & .000 & .078 \\
\hline Intellectual capital & - Product and Process Innovation & .082 & .082 & .000 & & \\
\hline
\end{tabular}




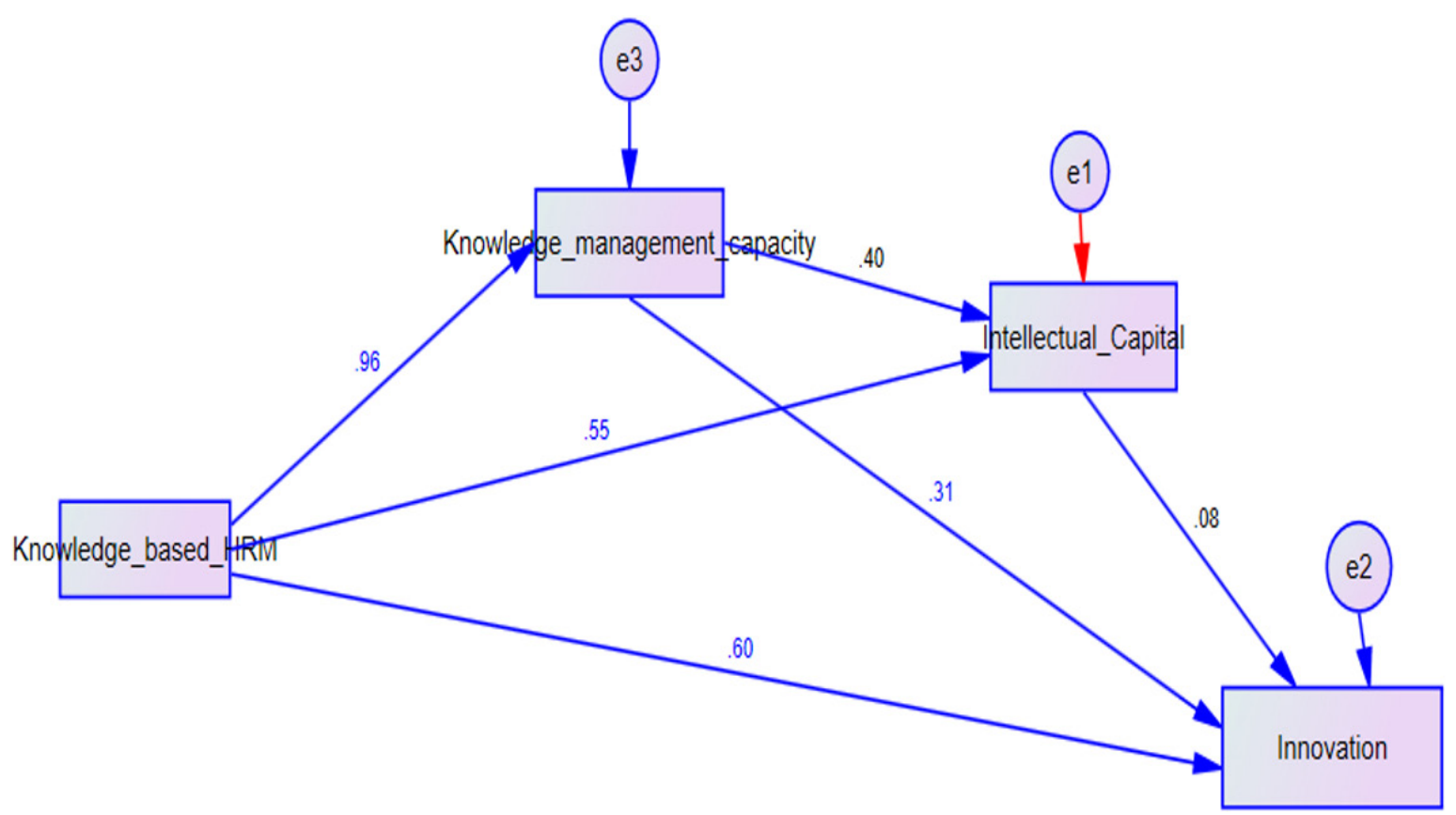

Figure 2: Structural model

Third, knowledge-based HRM practices have positive influence on product and process innovations of SMEs, implying that the strength of process and product innovativeness of an SMEs cannot be dissociated from its reliance on HRM. This finding also supports that of Cooke and Saini (2010) who investigated the role of human resource strategies on the innovative process of business. Fourthly, the paper revealed that knowledge management capacity has a positive influence on intellectual capital of SMEs employees. The outcome of this study, implies that developing intellectual capital in SMEs required effective knowledge management (Jordão \& Novas, 2017). To attain substantial level of innovativeness, firm must take advantage of its intellectual capital in creating new value. Fifth, this paper revealed that knowledge management capacity has a positive influence on product and process innovations of SMEs. This result suggests that beyond knowledge management capacity influence on intellectual capital, it also significantly impacts firms' innovativeness directly. Having this result help, us to understand that knowledge both tacit and explicit are essential building blocks for firm's innovation. This result also confirms and support the existing body of knowledge in this context (Hussinki et al., 2017).

Sixth, this paper revealed that intellectual capital of SMEs employees has positive influence on product and process innovations, implying that intellectual capital facilitates innovation through appropriate use of codified knowledge by employees (Donate \& de Pablo, 2015). Prior studies have linked innovation to intellectual capital of the firm (Donate et al., 2016; Kianto et al., 2017). Lastly, this paper confirmed the mediating effect of knowledge management capacity and intellectual capital on the relationship between knowledge-based HRM and, process and product innovation. This finding is crucial in that it elicit other mechanism that may enhance the influence of knowledge-based human resources practices on innovation. Apart from the contribution of this study in filling the gap in literature that seek to understand the mechanism for optimal influence of knowledge-based HRM practice on innovation, this finding also signifies the need for SMEs to pay adequate attention to knowledge systems and intellectual capital within their establishments.

\subsection{Implications for theory and practice}

Although studies have recognized the importance of knowledge-based HRM in SMEs, research examining cogent issues within this context is lacking (e.g., Nasution et al., 2011; Nicolau \& Santa-Mara, 2013), and the current study provide an empirically proven result that highlights and confirm the importance of knowledge-based HRM in SMEs. The model presented in this research provide managers with tool for conceptual thinking regarding the mechanisms they can deploy in their firms when aspiring to produce novel value-adding products and services. This paper's perspective is centered on knowledge flow in organization from HR practices to innovation. This assertion is consistent with Knowledge-Based View (KBV) theory, that is modeled with much reference and impetus 
Resource-Based View (RBV) of the firm. The missing link is that RBV does not give knowledge much attention, because knowledge is considered as a generic resource. To amend these drawbacks, KBV emphasis the strategic importance of knowledge-based resources that portend firms competitive advantage. Theoretically, this paper contributes to knowledge management and human resources management research stream by linking knowledge-based HRM with innovation through knowledge management capacity and intellectual capital. In sum, the present study validates the assumption of KBV.

This paper recommends that managers should create enabling work environment that will harness the benefits of KMS through knowledge-based HRM practices. Finally, process and product innovation can reach its peak when knowledge-based HRM practices is augmented with adequate knowledge management capacity and intellectual capital. As such, managers must encourage teamwork that will facilitate knowledge exploration, development and sharing among their personnel's. Practically, the findings from this study can be implemented by top management of organization who are concerned with transforming their human capital into organizational success. It is worthwhile to acknowledge that this paper inherits several limitations as follows. One, data was gleaned using a self-report approach with subject the outcome to social desirability bias. Two, data was gleaned at a single point using single source, thus, causal inference may have effect on the outcome. Three, although random sampling technique was utilized but sample size seems small, which questions the representativeness of the sample. The current outcome is limited to Jordan and cannot be generalized to other countries and cultural work settings with more resources.

\section{References}

Abubakar, A. M., Elrehail, H., Alatailat, M. A., \& Elçi, A. (2017). Knowledge management, decision-making style and organizational performance. Journal of Innovation \& Knowledge, https://doi.org/10.1016/j. jik.2017.07.003

Abubakar, A. M., Megeirhi, H. A., \& Shneikat, B. (2018). Tolerance for workplace incivility, employee cynicism and job search behavior. The Service Industries Journal, 38(9-10), 629-643, https://doi.org/10.1080/02642 $\underline{069.2017 .1420171}$

Alavi, M., \& Leidner, D. E. (2001). Review: Knowledge management and knowledge management systems: Conceptual foundations and research issues. MIS Quarterly, 107-136.

Anderson, J. C., \& Gerbing, D. W. (1988). Structural equation modeling in practice: a review and recommended two-step approach. Psychology Bulletin, 103 (3), 411-433

Bagozzi, R. P., \& Yi, Y. (1988). On the evaluation of struc- tural equation models. Journal of Academy of Marketing Science, 16 (1), 74-94, http://dx.doi.org/10.1007/ BF02723327

Bamberger, P. A., Biron, M., \& Meshoulam, I. (2014). Human resource strategy: Formulation, implementation, and impact. Routledge.

Bontis, N. (2004). National intellectual capital index: a United Nations initiative for the Arab region. Journal of Intellectual Capital, 5(1), 13-39.

Breaugh, J. A., \& Starke, M. (2000). Research on employee recruitment: So many studies, so many remaining questions. Journal of Management, 26(3), 405-434, https:// psycnet.apa.org/doi/10.1177/014920630002600303

Cabello-Medina, C., López-Cabrales, Á., \& Valle-Cabrera, R. (2011). Leveraging the innovative performance of human capital through HRM and social capital in Spanish firms. The International Journal of Human Resource Management, 22(4), 807-828, http://doi.org/ $\underline{10.1080 / 09585192.2011 .555125}$

Cabrera, E. F., \& Cabrera, A. (2005). Fostering knowledge sharing through people management practices. The International Journal of Human Resource Management, 16(5), 720-735, https://doi. org/10.1080/09585190500083020

Chang, S., Gong, Y., Way, S. A., \& Jia, L. (2013). Flexibility-oriented HRM systems, absorptive capacity, and market responsiveness and firm innovativeness. Journal of Management, 39(7), 1924-1951, https://doi. org/10.1177\%2F0149206312466145

Collins, C. J., \& Clark, K. D. (2003). Strategic human resource practices, top management team social networks, and firm performance: The role of human resource practices in creating organizational competitive advantage. Academy of Management Journal, 46(6), 740-751.

Combs, J., Liu, Y., Hall, A., \& Ketchen, D. (2006). How much do high-performance work practices matter? A meta-analysis of their effects on organizational performance. Personnel Psychology, 59(3), 501-528.

Cooke, F. L., \& Saini, D. S. (2010). (How) does the HR strategy support an innovation oriented business strategy? An investigation of institutional context and organizational practices in Indian firms. Human Resource Management, 49(3), 377-400, https://doi.org/10.1002/ $\underline{\text { hrm. } 20356}$

Damodaran, L., \& Olphert, W. (2000). Barriers and facilitators to the use of knowledge management systems. Behaviour \& Information Technology, 19(6), 405-413, http://doi.org/10.1080/014492900750052660

Darroch, J., \& McNaughton, R. (2002). Examining the link between knowledge management practices and types of innovation. Journal of Intellectual Capital, 3(3), 210222, https://doi.org/10.1108/14691930210435570

De Saá-Pérez, P., \& Diaz-Diaz, N. L. (2010). Human resource management and innovation in the Canary Islands: an ultra-peripheral region of the European 
Union. The International Journal of Human Resource Management, 21(10), 1649-1666, https://doi.org/10.1 080/09585192.2010.500488

de Ven, A. H. (1986). Central problems in the management of innovation. Management Science, 32(5), 590-607, https://doi.org/10.1287/mnsc.32.5.590

De Winne, S., \& Sels, L. (2010). Interrelationships between human capital, HRM and innovation in Belgian start-ups aiming at an innovation strategy. The International Journal of Human Resource Management, 21(11), 1863-1883, https://doi.org/10.1080/09585192 .2010 .505088

Delaney, J. T., \& Huselid, M. A. (1996). The impact of human resource management practices on perceptions of organizational performance. Academy of Management Journal, 39(4), 949-969, https://www.jstor.org/ $\underline{\text { stable } / 256718}$

Donate, M. J., \& de Pablo, J. D. S. (2015). The role of knowledge-oriented leadership in knowledge management practices and innovation. Journal of Business Research, 68(2), 360-370, https://doi.org/10.1016/j. ibusres.2014.06.022

Donate, M. J., Peña, I., \& de Pablo, J. D. (2016). HRM practices for human and social capital development: effects on innovation capabilities. The International Journal of Human Resource Management, 27(9), 928953, https://doi.org/10.1080/09585192.2015.1047393

Easterby-Smith, M., Lyles, M. A., \& Tsang, E. W. K. (2008). Inter-organizational knowledge transfer: Current themes and future prospects. Journal of Management Studies, 45(4), 677-690, https://doi.org/10.1111/ j.1467-6486.2008.00773.x

Engelman, R. M., Engelman, R. M., Fracasso, E. M., Fracasso, E. M., Schmidt, S., Schmidt, S., ... Zen, A. C. (2017). Intellectual capital, absorptive capacity and product innovation. Management Decision, 55(3), 474-490, https://doi.org/10.1108/MD-05-2016-0315

Elrehail, H., Emeagwali, O. L., Alsaad, A., \& Alzghoul, A. (2018). The impact of transformational and authentic leadership on innovation in higher education: the contingent role of knowledge sharing. 5(1), 55-67, https:// doi.org/10.1016/j.tele.2017.09.018

Fornell, C., \& Larcker, D., (1981). Evaluating structural equation models with unobservable and measurement error. Journal of Marketing Research, 18(1), 39-50, http://doi.org/10.2307/3151312

Gil-Marques, M., \& D. Moreno-Luzon, M. (2013). Driving human resources towards quality and innovation in a highly competitive environment. International Journal of Manpower, 34(8), 839-860, https://doi. org/10.1108/IJM-07-2013-0183

Gloet, M., \& Berrell, M. (2003). The dual paradigm nature of knowledge management: implications for achieving quality outcomes in human resource management. Journal of Knowledge Management, 7(1), 78-89, https://dx.doi.org/10.1108/13673270310463635
Gonzalez, E., Arrondo, R., \& Carcaba, A. (2017). Product innovation in the Spanish auto market: Frontier shift and catching-up effects. Transportation Research Part D: Transport and Environment, 50, 170-181, http://dx.doi.org/10.1016\%2Fj.trd.2016.10.024

Hair Jr., J. F., Black, W. C., Babin, B. J., \& Anderson, R. E. (2010). Multivariate data analysis: A global perspective, 7th ed. Pearson Prentice Hall, Upper Saddle River, NJ.

Hayes, F. (2015). An Index and Test of Linear Moderated Mediation, Multivariate Behavioral Research, 50(1), 1-22, http://doi.org/10.1080/00273171.2014.962683

Huggins, R., \& Thompson, P. (2015). Entrepreneurship, innovation and regional growth: a network theory. Small Business Economics, 45(1), 103-128.

Hussinki, H., Ritala, P., Vanhala, M., \& Kianto, A. (2017). Intellectual capital, knowledge management practices and firm performance. Journal of Intellectual Capital, 18(4), 904-922, https://doi.org/10.1108/JIC-11-20160116

Inkinen, H. T., Kianto, A., \& Vanhala, M. (2015). Knowledge management practices and innovation performance in Finland. Baltic Journal of Management, 10(4), 432-455, https://doi.org/10.1108/BJM-102014-0178

Jahmani, K., Fadiya, S. O., Abubakar, A. M., \& Elrehail, H. (2018). Knowledge management system content quality, perceived usefulness, use for sharing and retrieval: A Flock Leadership application. VINE Journal of Information and Knowledge Management Systems, (just-accepted), https://doi.org/10.1108/ VJIKMS-08-2017-005

Jiang, J., Wang, S., \& Zhao, S. (2012). Does HRM facilitate employee creativity and organizational innovation? A study of Chinese firms. The International Journal of Human Resource Management, 23(19), 4025-4047, http://dx.doi.org/10.1080/09585192.2012.690567

Jiang, K., Lepak, D. P., Hu, J., \& Baer, J. C. (2012). How does human resource management influence organizational outcomes? A meta-analytic investigation of mediating mechanisms. Academy of Management Journal, 55(6), 1264-1294, https://doi.org/10.5465/ amj.2011.0088

Jordão, R. V. D., \& Novas, J. C. (2017). Knowledge management and intellectual capital in networks of small and medium-sized enterprises. Journal of Intellectual Capital, https://doi.org/10.1108/JIC-11-2016-0120

Kang, S.-C., Snell, S. A., \& Swart, J. (2012). Options-based HRM, intellectual capital, and exploratory and exploitative learning in law firms' practice groups. Human Resource Management, 51(4), 461-485, http://doi. org/10.1002/hrm.21484

Kehoe, R. R., \& Wright, P. M. (2013). The impact of high-performance human resource practices on employees' attitudes and behaviors. Journal of Management, 39(2), 366-391, http://doi. 
org/10.1177/0149206310365901

Kianto, A., Ritala, P., Spender, J.-C., \& Vanhala, M. (2014). The interaction of intellectual capital assets and knowledge management practices in organizational value creation. Journal of Intellectual Capital, 15(3), 362375, http://doi.org/10.1108/JIC-05-2014-0059

Kianto, A., Sáenz, J., \& Aramburu, N. (2017). Knowledge-based human resource management practices, intellectual capital and innovation. Journal of Business Research, 81, 11-20, http://doi.org/10.1016/j.jbusres.2017.07.018

Kogut, B., \& Zander, U. (2003). Knowledge of the firm and the evolutionary theory of the multinational corporation. Journal of International Business Studies, 34(6), 516-529, https://doi.org/10.1057/palgrave. jibs. 8400058

Lau, C.-M., \& Ngo, H.-Y. (2004). The HR system, organizational culture, and product innovation. International Business Review, 13(6), 685-703.

Lewis, S., \& Arnold, J. (2012). Organisational career management in the UK retail buying and merchandising community. International Journal of Retail \& Distribution Management, 40(6), 451-470, https://doi. org/10.1108/09590551211230269

Liao, C., Chuang, S.-H., \& To, P.-L. (2011). How knowledge management mediates the relationship between environment and organizational structure. Journal of Business Research, 64(7), 728-736, https://doi. org/10.1016/j.jbusres.2010.08.001

Lichtenthaler, U. (2015). A note on outbound open innovation and firm performance. $R \& D$ Management, 45(5), 606-608, https://doi.org/10.1111/radm.12138

Likoum, S. W. B., Shamout, M. D., Harazneh, I., \& Abubakar, A. M. (2018). Market-Sensing Capability, Innovativeness, Brand Management Systems, Market Dynamism, Competitive Intensity, and Performance: An Integrative Review. Journal of the Knowledge Economy, 1-21.

Lin, H.-F. (2011). An empirical investigation of mobile banking adoption: The effect of innovation attributes and knowledge-based trust. International Journal of Information Management, 31(3), 252-260, https://doi. org/10.1016/j.ijinfomgt.2010.07.006

López-Nicolás, C., \& Meroño-Cerdán, Á. L. (2011). Strategic knowledge management, innovation and performance. International Journal of Information Management, 31(6), 502-509, https://doi.org/10.1016/j. ijinfomgt.2011.02.003

MacKenzie, S. B., Podsakoff, P. M., \& Podsakoff, N. P. (2011). Construct measurement and validation procedures in MIS and behavioral research: Integrating new and existing techniques. MIS Quarterly, 35(2), 293334, https://doi.org/10.2307/23044045

Mahdavi Mazdeh, M., \& Hesamamiri, R. (2014). Knowledge management reliability and its impact on organizational performance: an empirical study. Program,
48(2), 102-126, https://doi.org/10.1108/AJIM-082014-0109

Manzaneque, M., Ramirez, Y., \& Diéguez-Soto, J. (2017). Intellectual capital efficiency, technological innovation and family management. Innovation, 19(2), 167-188, https://doi.org/10.1080/14479338.2016.1272828

Martini, A., Neirotti, P., \& Appio, F. P. (2017). Knowledge searching, integrating and performing: always a tuned trio for innovation? Long Range Planning, 50(2), 200-220, https://doi-org.ezproxy.lib.ukm.si/10.1016/j. lrp.2015.12.020

Martinsons, M. G. (1995). Knowledge-based systems leverage human resource management expertise. International Journal of Manpower, 16(2), 17-34, https://doi. org/10.1108/01437729510085747

Massey, A. P., Montoya-Weiss, M., \& O'Driscoll, T. M. (2008). Transforming the new product development process. Business Process Transformation, 185.

May, D. R., \& Flannery, B. L. (1995). Cutting waste with employee involvement teams. Business Horizons, 38(5), 28-38.

Mendoza, R. R. (2017). Relationship between intangible assets and cash flows: an empirical analysis of publicly listed corporations in the Philippines. Review of Integrative Business and Economics Research, 6(1), 188-202.

Miller, D. J., Fern, M. J., \& Cardinal, L. B. (2007). The use of knowledge for technological innovation within diversified firms. Academy of Management Journal, 50(2), 307-325, http://doi.org/10.5465/ AMJ.2007.24634437

Moreno-Luzon, M. D., Gil-Marques, M., \& Valls-Pasola, J. (2013). TQM, innovation and the role of cultural change. Industrial Management \& Data Systems, 113(8), 1149-1168, https://doi.org/10.1108/IMDS-022013-0075

Nasution, H. N., Mavondo, F. T., Matanda, M. J., \& Ndubisi, N. O. (2011). Entrepreneurship: Its relationship with market orientation and learning orientation and as antecedents to innovation and customer value. Industrial Marketing Management, 40(3), 336-345, https:// doi.org/10.1016/j.indmarman.2010.08.002

Nicolau, J. L., \& Santa-Mara, M. J. (2013). The effect of innovation on hotel market value. International Journal of Hospitality Management, 32, 71-79.

Nieves, J., Quintana, A., \& Osorio, J. (2014). Knowledge-based resources and innovation in the hotel industry. International Journal of Hospitality Management, 38, 65-73, http://dx.doi.org/10.1016/j. ijhm.2014.01.001

Nonaka, I. (1994). A dynamic theory of organizational knowledge creation. Organization Science, 5(1), 1437, http://www.jstor.org/stable/2635068

Nonaka, I., \& Takeuchi, H. (1995). The knowledge-creating company: How Japanese companies create the dynamics of innovation. Oxford University Press. 
Obeidat, B. Y., Tarhini, A., Masa'deh, R., \& Aqqad, N. O. (2017). The impact of intellectual capital on innovation via the mediating role of knowledge management: a structural equation modelling approach. International Journal of Knowledge Management Studies, 8(3-4), 273-298, https://doi.org/10.1504/IJKMS.2017.087071

Ortiz, B., Donate, M. J., \& Guadamillas, F. (2016). Relational and Cognitive Social Capital: Their Influence on Strategies of External Knowledge Acquisition. Procedia Computer Science, 99, 91-100, https://doi. org/10.1016/j.procs.2016.09.103

Ozlen, K., \& Handzic, M. (2014). An empirical test of a contingency model of KMS effectiveness. Knowledge Management Research \& Practice, 12(1), 1-11. https://doi.org/10.1057/kmrp.2012.34

Perry-Smith, J. E., \& Mannucci, P. V. (2017). From creativity to innovation: The social network drivers of the four phases of the idea journey. Academy of Management Review, 42(1), 53-79, https://doi.org/10.5465/ amr.2014.0462

Petruzzelli, A. M. (2011). The impact of technological relatedness, prior ties, and geographical distance on university--industry collaborations: A joint-patent analysis. Technovation, 31(7), 309-319, http://doi. org/10.1016/j.technovation.2011.01.008

Robbins, S. P., Judge, T., \& Campbell, T. T. (2010). Organizational behaviour. Financial Times Prentice Hall.

Rodan, S., \& Galunic, C. (2004). More than network structure: How knowledge heterogeneity influences managerial performance and innovativeness. Strategic Management Journal, 25(6), 541-562, http://doi.org/ 10.1002/smj.398

Rosenbach, W. E., Taylor, R. L., \& Youndt, M. A. (2012). Contemporary issues in leadership. Westview Press.

Rousseau, M. B., Mathias, B. D., Madden, L. T., \& Crook, T. R. (2016). Innovation, firm performance, and appropriation: A meta-analysis. International Journal of Innovation Management, 20(3), 1650033, http://doi. org/10.1142/S136391961650033X

Serenko, A., Bontis, N., \& Hull, E. (2016). An application of the knowledge management maturity model: the case of credit unions. Knowledge Management Research \& Practice, 14(3), 338-352, https://doi. org/10.1057/kmrp.2014.37

Shipton, H., West, M. A., Dawson, J., Birdi, K., \& Patterson, M. (2006). HRM as a predictor of innovation. Human Resource Management Journal, 16(1), 3-27, https://doi.org/10.1111/j.1748-8583.2006.00002.x

Shrafat, F. D. (2017). Examining the factors influencing knowledge management system (KMS) adoption in small and medium enterprises SMEs. Business Process Management Journal, (just-accepted), 0.

Singh, H., Kryscynski, D., Li, X., \& Gopal, R. (2016). Pipes, pools, and filters: how collaboration networks affect innovative performance. Strategic Management Journal, 37(8), 1649-1666.
Siong, C., Kuan Yew, W., \& Lin, B. (2006). Criteria for measuring KM performance outcomes in organisations. Industrial Management \& Data Systems, 106(7), 917-936, http://doi.org/10.1108/02635570610688850

Škerlavaj, M., Song, J.H., Lee, Y. (2010). Organizational learning culture, innovative culture and innovations in South Korean firms. Expert Systems Application, 37 (9), 6390-6403, http://dx.doi.org/10.1016/j. eswa.2010.02.080

Snell, S. A., \& Dean, J. W. (1992). Integrated manufacturing and human resource management: A human capital perspective. Academy of Management Journal, 35(3), 467-504, https://psycnet.apa.org/doi/10.2307/256484

Soto-Acosta, P., Popa, S., \& Palacios-Marqués, D. (2016). E-business, organizational innovation and firm performance in manufacturing SMEs: an empirical study in Spain. Technological and Economic Development of Economy, 22(6), 885-904, https://doi.org/10.3846/20 294913.2015.1074126

Soto-Acosta, P., Popa, S., \& Palacios-Marqués, D. (2017). Social web knowledge sharing and innovation performance in knowledge-intensive manufacturing SMEs. The Journal of Technology Transfer, 42(2), 425-440, http://doi.org/10.1007/s10961-016-9498-z

Spithoven, A., Vanhaverbeke, W., \& Roijakkers, N. (2013). Open innovation practices in SMEs and large enterprises. Small Business Economics, 41(3), 537-562, http://doi.org/ 10.1007/s11187-012-9453-9

Stewart, T. (1997). The new wealth of organizations. London: Nicholas Brealey.

Subramaniam, M., \& Youndt, M. A. (2005). The influence of intellectual capital on the types of innovative capabilities. Academy of Management Journal, 48(3), 450-463, https://doi.org/10.5465/amj.2005.17407911

Sun, L.-Y., \& Pan, W. (2011). Differentiation strategy, high-performance human resource practices, and firm performance: Moderation by employee commitment. The International Journal of Human Resource Management, 22(15), 3068-3079, https://psycnet.apa.org/ doi/10.1080/09585192.2011.560860

Swart, J., \& Kinnie, N. (2013). Managing multidimensional knowledge assets: HR configurations in professional service firms. Human Resource Management Journal, 23(2), 160-179, https://doi.org/10.1111/j.1748$\underline{8583.2012 .00197 . x}$

Tsai, K.-H., \& Hsu, T. T. (2014). Cross-Functional collaboration, competitive intensity, knowledge integration mechanisms, and new product performance: A mediated moderation model. Industrial Marketing Management, 43(2), 293-303, http://doi.org/10.1016/j.indmarman.2015.02.030

Wang, D., \& Chen, S. (2013). Does intellectual capital matter? High-performance work systems and bilateral innovative capabilities. International Journal of Manpower, 34(8), 861-879, https://doi.org/10.1108/IJM$\underline{07-2013-0167}$ 
Weisman, V. L. (1999). The impact of facilitative leadership: Multi-rater measurement of behavioral outcomes of managerial-leaders. In Academy of Human Resource Development Conference Proceedings (pp. 384-403).

West, J., Salter, A., Vanhaverbeke, W., \& Chesbrough, H. (2014). Open innovation: The next decade. Elsevier.

Yang, C.-C., \& Lin, C. Y.-Y. (2009). Does intellectual capital mediate the relationship between HRM and organizational performance? Perspective of a healthcare industry in Taiwan. The International Journal of Human Resource Management, 20(9), 1965-1984, https://doi. org/10.1080/09585190903142415

Zack, M., McKeen, J., \& Singh, S. (2009). Knowledge management and organizational performance: an exploratory analysis. Journal of Knowledge Management, 13(6), 392-409, https://doi. org/10.1108/13673270910997088

Mohammad Jaber Yousef Al-tal is a PhD candidate at Girne American University, Cyprus, Faculty of Economics and Business, Business Management Department. He is human resources specialist with 14 years of experience. He is employed at Prime Ministry of Hashemite Kingdom of Jordan as the department head of administrative affairs. His research focuses on human resources management and organizational behavior.

Okechukwu Lawrence Emeagwali, PhD, is Associate Professor of Strategic Management at the American University Cyprus. $\mathrm{He}$ is also the head of the Department of Business Management and the director of the Center for Management Research (CMR), housed in the Faculty of Business and Economics. He lectures, speaks, advises and researches on topics bordering around business strategy and general business management. His research interests lie within the strategic management field, particularly the action-based competitive interaction sub-stream of the competitive dynamics research area. He links his research, practice and teaching experiences to provide practical recommendations and unique insights to the various academic and corporate stakeholder groups he is currently involved with. 